Volume: 13 Issue: 2 Year: 2016

\title{
Investigation of the job satisfaction and burnout levels of the wrestling referees according to various factors in Turkey ${ }^{1}$
}

\author{
Taha Yasin Ilkım ${ }^{2}$ \\ Mehmet Güllü
}

\begin{abstract}
The purpose of this study was to examine the job satisfaction and professional burnout levels of the national and international wrestling referees in terms of various factors in Turkey.

The method of the study was the descriptive method. The study group consists of 126 international and national wrestling referees on active duty in 2010-2011 wrestling season. The questionnaire form was used as the data collection tool in the study. The questionnaire form consists of 3 sections, which are the Personal Information Form, the Maslach Burnout Inventory, and the Job Satisfaction Scale. It was observed abnormal distribution of dates of inventory and scale according to the Kolmogorov-Smirnov Test. Due to this reason, the Mann-Whitney U Test was used for the two independent samples test in analyzing the data; the Kruskal-Wallis H Test and the Mann-Whitney U Tests with Bonferroni correction were used for multiple comparisons; and the Spearman Correlation was used in analyzing the relations. The critical point for the significance value was accepted as $\alpha=0.05$

It was determined in the light of the findings of the study that the job satisfaction of the wrestling referees were at the medium level; the emotional exhaustion levels were high; the depersonalization levels were medium; and personal accomplishment levels were low. Significant difference was found among the depersonalization levels of the referees according to the referee categories of the wrestling referees $(p<0,05)$. A significant difference has been found among the monthly average income levels and the emotional exhaustion levels of the wrestling referees $(\mathrm{p}<0,05)$. A significant difference was also determined among the viewpoints of the referees on the financial income of the referees and the job satisfaction levels according to the social status $(p<0,05)$. In addition, a reverse, significant and weak relation was found between the job satisfaction and emotional exhaustion levels of the referees $(r=-0,255, p<0,01)$; a reverse, significant and weak relation between the depersonalization $(\mathrm{r}=-0,97, \mathrm{p}<0,01)$; and a weak positive relation was determined between the personal accomplishment levels $(r=0,341, p<0,01)$.

As a result, the national and international wrestling referees in Turkey do not have adequate satisfaction from being referees, and are experiencing professional burnout. As the job satisfaction levels of the wrestling referees increase, depersonalization levels and emotional exhaustion levels decrease, and personal accomplishment levels increase.
\end{abstract}

Keywords: Wrestling, Referee, Job Satisfaction, Burnout, International Referee

\footnotetext{
1 This article was derived from the master's thesis prepared at the Health Sciences Institute at Inonu University.

2 Inonu University, Department of Sport, Malatya, Turkey, taha.ilkim@inonu.edu.tr

${ }^{3}$ Assist. Prof. Dr., Inonu University, Physical Education and Sports School, Department of Physical Education and Sport Teacher, Malatya, Turkey. mehmet.gullu@inonu.edu.tr (corresponding author)
} 
Ilkım, Y.T., \& Güllü, M. (2016). Investigation of the job satisfaction and burnout levels of the wrestling referees according to various factors in Turkey. Journal of Human Sciences, 13(2), 3469-3481. doi:10.14687/jhs.v13i2.4008

\section{Introduction}

In general sense, a referee is defined as the person whom parties choose and agree on as the authorized person to resolve the conflicts between them (TLA, 2006). In sports, the person, who is in the playground to manage a game or competition without violating the rights of the parties by being devoted to the objectivity principle to reach the best performance by applying the rules of the game or the competition, is defined as a referee (Cei, 1994; Tekgöz, 2013).

It is clear that referees are necessary and important for all branches. It is only possible to perform all sports competitions within a certain order and under the supervision of rules with the perfect management of referees. The psychological and physiological status of one or more referees may change the proceeding of a competition and influence the results. Referees are subject to many pressures both on the fields and outside the fields. After each competition, they are held responsible for positive or negative results; and most important than all, their personalities are interpreted in various manners. All these developments have negative influences on referees both in psychological and mental terms (Cei, 1994; Sülün, 2013). In such situations, referees may experience burnout syndromes and their satisfaction levels may decrease for their profession.

The term "burnout" expresses the situation in which a person loses his/her strength and not tries to show effort (TLA, 2016). Burnout has been defined as a physical and mental syndrome which appears in a person together with physical fatigue, long-term exhaust, being desperate and hopeless; and covers the negative attitudes of a person to his/her job and to the other people around (Maslach \& Jackson, 1981). In other words, the burnout syndrome is the emotion of being excessively under pressure and being exhausted because of the job done by that person (Aslan et al., 1997).

Freudenberger in 1974 examined the burnout syndrome, which is also accepted as a type of job stress, under three main dimensions. The first dimension starts with emotional exhaustion (exhaust, wear). The second dimension consists of the negative, cynical attitudes and emotions of the individual developed against the job $\mathrm{s} / \mathrm{he}$ does, and this dimension is defined as the desensitization. The third dimension is the negative evaluation of the individual about his/her job; in other words, the feeling of failure (as cited in Sucuoğlu \& Kuloğlu, 1996). The increase in burnout syndrome, emotional exhaust and desensitization in the individual appear with the decrease of the personal accomplishment and the sense of success. The low-level job performance of an individual, his/her absenteeism at work, not performing the functions of the job, which are all the results of burnout, are accepted as a social problem (Sucuoğlu \& Kuloğlu, 1996; Sünter et al., 2006).

Another emotional aspect influencing the job life is the job satisfaction. Unlike the feeling of burnout, if the job satisfaction is high, this influences the individual in a positive way. The job satisfaction, which is one of the necessities of individuals for being successful, happy and productive, is the emotion of being content when the contributions of the individual are perceived. The job satisfaction is also the emotional reaction developed by the individual as a result of his/her evaluations of the job and job environment. All employees demand that the working conditions are improved, and the economic, psychological and social desires and demands related with their work are covered. As long as the demands of the employees are covered in a workplace, they have job satisfaction (Kurçer, 2005). Job satisfaction is described as the pleasure as a result of the evaluation of the individual about his/her job, or as the emotional contentment as a result of the emotional satisfaction at work. It is accepted that job satisfaction is related with life satisfaction, and influences the physical and spiritual health of the individuals in a direct manner. Job satisfaction is only possible with organizing working conditions and working environment, increasing the quality of the work life, and the reduction of the employees to the level of being social in psychological and economical terms (Akçamete et al., 2001).

Job satisfaction and the burnout syndrome may influence wrestling referees as well as the other employees in all areas of life. Wrestling referees play important roles in developing, spreading and sustaining wrestling, which is known as the ancestor sport of the Turks (Gökdemir, 1991; 
Ilkım, Y.T., \& Güllü, M. (2016). Investigation of the job satisfaction and burnout levels of the wrestling referees according to various factors in Turkey. Journal of Human Sciences, 13(2), 3469-3481. doi:10.14687/ihs.v13i2.4008

Bayraktar \&Tozoğlu, 2015). The burnout status of a referee or his/her job satisfaction level may influence his/her instant decisions during sports competitions. A wrong decision of a Wrestling Referee may change the course of the competition; and a wrestler, who may achieve better success in future, may easily lose the competition. For this reason, referees need to be in good psychological situation when they are making decisions, and the situations that influence their decisions must be eliminated. For this, it is necessary to know the cognitive, psychological, social etc. characteristics of the referees.

\section{Purpose}

The purpose of this study is to examine the professional burnout and job satisfaction levels of the senior National and International wrestling referees according to various factors, and to reveal the relation between the professional burnout and job satisfaction levels of the referees.

\section{Method and Material}

The descriptive method has been used in the study. The study group consisted of 126 volunteering wrestling referees out of the 180 National and International wrestling referees, who were on active duty in 2010-2011 wrestling season, in Turkey. The necessary permission was received from the Wrestling Federation of Turkey for the study (TGF/146-2011).

\subsection{Data Collection Tools}

The Questionnaire form has been used in the study as the data collection tool. The questionnaire form consists of three sections, which are the personal information form consisting of 14 questions; the Maslach Burnout Inventory (Maslach \& Jackson, 1981; Ergin, 1999) and the Job Satisfaction Scale (Güler, 1990).

\subsubsection{Maslach Burnout Inventory}

The Maslach Burnout Inventory was developed by Maslach and Jackson (1981), and was translated into Turkish by Ergin (1999). The adaptation into Turkish consists of 5-point answer choices, which are "Never; Very Rarely; Sometimes; Mostly; Always". There are 3 sub-dimensions: Emotional Exhaustion: This sub-dimension defines the situation in which the person is exhausted by his/her job and being excessively overloaded, and consists of 9 items. Depersonalization: This sub-dimension defines the behavior of the individuals acting without emotions and without caring for the fact that individuals are specific entities in the face of people they serve to, and consists of 5 items. Personal Accomplishment: This sub-dimension defines the emotions of overcoming situations with success, and proficiency in an individual who works with other people, and consists of 8 items (Ergin, 1999).

Table 1. Evaluation of the Points that will be Included in the Sub-dimensions of the Maslach Burnout Inventory

\begin{tabular}{lccc}
\hline Sub-dimensions & Low & Medium & High \\
\hline Emotional Exhaustion & $0-11$ & $12-17$ & 18 and Over \\
Depersonalization & $0-5$ & $6-9$ & 10 and Over \\
Personal Accomplishment & 26 and Over & $22-25$ & $0-21$ \\
\hline
\end{tabular}

\subsubsection{Job Satisfaction Scale}

The Job Satisfaction Scale, which is also known as "Job Diagnostic Survey (JDS)", was developed by Hackman and Oldham in 1980, and was translated into Turkish by Gödelek in 1988. 
Ilkım, Y.T., \& Güllü, M. (2016). Investigation of the job satisfaction and burnout levels of the wrestling referees according to various factors in Turkey. Journal of Human Sciences, 13(2), 3469-3481. doi:10.14687/ihs.v13i2.4008

The scale is a 5-Point Likert scale with one single dimension consisting of 15 questions. The lowest point that can be received from the scale is 15 points, and the highest point is 70 (as cited in Güler, 1990).

Table 2. Evaluation of the Points that can be received in the Job Satisfaction Scale

\begin{tabular}{llll}
\hline & Low & Medium & High \\
\hline Job Satisfaction & $14-32$ & $33-52$ & $53-70$ \\
\hline
\end{tabular}

\subsection{Evaluation of Data}

The raw data received in the study have been analyzed with the Statistical Package Programs. It has been observed that the data received from the Maslach Burnout Scale and Job Satisfaction Scale do not show normal distribution according to the Kolmogrov-Smirnov Test. For this reason, it was used as a non-parametric tests applied in statistical analyses. The Mann-Whitney U Test was used for the two independent samples test; and the Kruskal-Wallis H Test was used for multiple comparisons then by following the Mann-Whitney U Test with Bonferroni Correction for post-hoc comparisons. The Spearman Correlation Analysis was used in analyzing the relations. The critical point for the significance value was accepted as $\alpha=0.05$

\section{Result}

Table 3. The Personal Information of the Wrestling Referees

\begin{tabular}{llcc}
\hline Personal Information & Categories & f & $\%$ \\
\hline Age & 30 Age and Below & 14 & 11,1 \\
& 31-40 Age & 62 & 49,2 \\
& $41-50$ Age & 37 & 29,4 \\
& 50 Age and Over & 13 & 10,3 \\
& Total & 126 & 100,0 \\
\hline Marital Status & Married & 116 & 92,1 \\
& Single & 10 & 7,9 \\
& Total & 126 & 100,0 \\
\hline Educational Status & Secondary School & 6 & 4,8 \\
& Undergraduate & 99 & 78,6 \\
& Postgraduate & 21 & 16,7 \\
& Total & 126 & 100,0 \\
\hline Original Profession & Office employee & 11 & 8,7 \\
& Employee & 8 & 6,3 \\
& Teacher & 63 & 50,0 \\
& Doctor & 2 & 1,6 \\
& Police & 7 & 5,6 \\
& Academician & 4 & 3,2 \\
& Manager & 6 & 4,8 \\
& Other & 25 & 19,8 \\
& Total & 126 & 100,0 \\
\hline Geographical Areas they live & Marmara & 22 & 17,5 \\
& Central Anatolia & 29 & 23,0 \\
& Aegean & 9 & 7,1 \\
& Mediterranean & 18 & 14,3 \\
& Black Sea & 27 & 21,4 \\
& Eastern Anatolia & 16 & 12,7 \\
& Southeastern Anatolia & 5 & 4,0 \\
& Total & 126 & 100,0 \\
\hline & & &
\end{tabular}


Ilkım, Y.T., \& Güllü, M. (2016). Investigation of the job satisfaction and burnout levels of the wrestling referees according to various factors in Turkey. Journal of Human Sciences, 13(2), 3469-3481. doi:10.14687/jhs.v13i2.4008

It is observed that there is the personal information of the wrestling referees involved in this research in table 3. It is seen that the most of wrestling referees are between 31-39 aged $(\% 49,2)$, married $(\% 92,1)$, undergraduate $(\% 78,6)$, teacher $(\% 50)$ and living in Central Anatolia region $(\% 23)$ in Turkey

Table 4. Evaluation of the Points of the Wrestling Referees from Job Satisfaction Scale and Professional Burnout Sub-dimensions

\begin{tabular}{lcccr}
\hline \multicolumn{1}{c}{ Scale / Sub-dimensions } & $n$ & $\bar{X}$ & Std. Dev. & \multicolumn{1}{c}{ Evaluation } \\
\hline Job Satisfaction scale & 126 & 46,11 & 10,50 & Medium level \\
Emotional Exhaustion Sub-dimensions & 126 & 19,39 & 5,19 & High level \\
Depersonalization Sub-dimensions & 126 & 9,13 & 3,28 & Medium level \\
Personal Accomplishment Sub-dimensions & 126 & 29,37 & 5,09 & Low level \\
\hline
\end{tabular}

It is observed that the job satisfaction of wrestling referees are at medium level $(\bar{X}$ $=46,11 \pm 10,50)$; emotional exhaustion $(\bar{X}=19,39 \pm 5,19)$ at high level; depersonalization ( $\bar{X}$ $=9,13 \pm 3,28)$ is at medium level; and personal accomplishment $(\bar{X}=29,37 \pm 5,09)$ is at low level in table 4 .

Table 5. The Distribution of the Job Satisfaction and Professional Burnout Points of the Wrestling Referees according to their Ages

\begin{tabular}{lllllll}
\hline $\begin{array}{l}\text { Scale } / \text { Sub- } \\
\text { dimensions }\end{array}$ & \multicolumn{1}{c}{ Age } & $\mathrm{n}$ & $\begin{array}{c}\text { Mean } \\
\text { Rank }\end{array}$ & KW & df & $\mathrm{p}$ \\
\hline Job Satisfaction scale & 30 age and below & 14 & 62,07 & & & \\
& $31-40$ age & 62 & 62,15 & 1,138 & 3 & 0,76 \\
& $41-50$ age & 37 & 62,73 & & & \\
& 50 age and over & 13 & 73,69 & & & \\
\hline Emotional & 30 age and below & 14 & 78,57 & & & \\
Exhaustion & $31-40$ age & 62 & 60,99 & 3,261 & 3 & 0,35 \\
Sub-dimensions & $41-50$ age & 37 & 60,18 & & & \\
& 50 age and over & 13 & 68,69 & & & \\
\hline Depersonalization & 30 age and below & 14 & 79,57 & & & \\
Sub-dimensions & $31-40$ age & 62 & 62,46 & 3,916 & 3 & 0,27 \\
& $41-50$ age & 37 & 57,70 & & & \\
\hline Personal & 50 age and over & 13 & 67,65 & & & \\
Accomplishment & 30 age and below & 14 & 55,43 & & & \\
Sub-dimensions & $31-40$ age & 62 & 66,15 & \multirow{2}{*}{2,736} & 3 & 0,43 \\
& $41-50$ age & 37 & 58,51 & & & \\
\hline & 50 age and over & 13 & 73,73 & & &
\end{tabular}

It is observed that no statistically significant difference $(p>0,05)$ was detected among the job satisfaction points and the professional burnout sub-dimensions points (emotional exhaustion, depersonalization, personal accomplishment) of the wrestling referees according to their ages in table 5 . 
Ilkım, Y.T., \& Güllü, M. (2016). Investigation of the job satisfaction and burnout levels of the wrestling referees according to various factors in Turkey. Journal of Human Sciences, 13(2), 3469-3481. doi:10.14687/jhs.v13i2.4008

Table 6. The Distribution of the Job Satisfaction and Professional Burnout Points of the Wrestling Referees according to their Marital Status

\begin{tabular}{|c|c|c|c|c|c|c|}
\hline $\begin{array}{l}\text { Scale /Sub- } \\
\text { dimensions }\end{array}$ & $\begin{array}{l}\text { Marital } \\
\text { Status }\end{array}$ & $\mathrm{n}$ & $\begin{array}{l}\text { Mean } \\
\text { Rank }\end{array}$ & $\begin{array}{c}\text { Sum of } \\
\text { Ranks }\end{array}$ & $\begin{array}{c}\text { Mann- } \\
\text { Whitney U }\end{array}$ & $\mathrm{p}$ \\
\hline \multirow{2}{*}{ Job Satisfaction scale } & Married & 116 & 64,09 & 7434,50 & \multirow{2}{*}{511,500} & \multirow{2}{*}{0,53} \\
\hline & Single & 10 & 56,65 & 566,50 & & \\
\hline \multirow{2}{*}{ Emotional Exhaustion } & Married & 116 & 61,90 & 7180,50 & \multirow{2}{*}{394,500} & \multirow{2}{*}{0,09} \\
\hline & Single & 10 & 82,05 & 820,50 & & \\
\hline \multirow{2}{*}{ Depersonalization } & Married & 116 & 63,15 & 7325,50 & \multirow{2}{*}{539,500} & \multirow{2}{*}{0,71} \\
\hline & Single & 10 & 67,55 & 675,50 & & \\
\hline Personal & Married & 116 & 64,45 & 7476,50 & \multirow{2}{*}{469,500} & \multirow{2}{*}{0,31} \\
\hline Accomplishment & Single & 10 & 52,45 & 524,50 & & \\
\hline
\end{tabular}

According to table 6, no statistically significant difference has been detected among the job satisfaction points and the professional burnout sub-dimensions points (emotional exhaustion, depersonalization, personal accomplishment) of the wrestling referees according to their marital status $(\mathrm{p}>0,05)$.

Table 7. The Distribution of Job Satisfaction and Professional Burnout Points of the Wrestling Referees according to their Monthly Average Incomes

\begin{tabular}{|c|c|c|c|c|c|c|c|c|}
\hline $\begin{array}{l}\text { Scale /Sub- } \\
\text { dimensions }\end{array}$ & Monthly Income & $\mathrm{n}$ & $\begin{array}{l}\text { Mean } \\
\text { Rank }\end{array}$ & KW & sd & $\mathrm{p}$ & Groups & $\mathrm{p}$ \\
\hline Job Satisfaction & 1000も and below & 4 & 40,25 & & & & & \\
\hline \multirow[t]{4}{*}{ scale } & 1001-1500も & 28 & 56,64 & & & & & \\
\hline & 1501-2000も & 63 & 64,46 & 4,106 & 4 & 0,39 & & \\
\hline & 2001-3000も & 19 & 73,24 & & & & & \\
\hline & 3001も and over & 12 & 66,79 & & & & & \\
\hline Emotional & 1000€ and below (1) & 4 & 66,12 & & & & & \\
\hline \multirow[t]{4}{*}{ Exhaustion } & 1001-1500も & 28 & 79,64 & & & & & \\
\hline & 1501-2000も & 63 & 59,68 & 11,417 & 4 & $0,02 *$ & $(2)-(4)$ & $0,003^{* *}$ \\
\hline & 2001-3000も & 19 & 45,92 & & & & & \\
\hline & 3001も and over (5) & 12 & 72,83 & & & & & \\
\hline \multirow{5}{*}{ Depersonalization } & 1000も and below & 4 & 43,38 & & & & & \\
\hline & 1001-1500も & 28 & 69,75 & & & & & \\
\hline & 1501-2000も & 63 & 63,70 & 3,267 & 4 & 0,51 & & \\
\hline & 2001-3000も & 19 & 55,08 & & & & & \\
\hline & 3001も and over & 12 & 67,92 & & & & & \\
\hline Personal & 1000も and below & 4 & 41,25 & & & & & \\
\hline \multirow[t]{4}{*}{ Accomplishment } & 1001-1500も & 28 & 60,64 & & & & & \\
\hline & 1501-2000も & 63 & 60,10 & 7,726 & 4 & 0,10 & & \\
\hline & 2001-3000も & 19 & 68,61 & & & & & \\
\hline & 3001も and over & 12 & 87,33 & & & & & \\
\hline
\end{tabular}

In table 7 , it is observed that there is no significant difference among personal accomplishment sub-dimension points, the job satisfaction points and professional burnout subdimension points, according to the monthly average incomes of the wrestling referees $(p>0,05)$. However, a significant difference has been detected among the emotional exhaustion sub- 
Ilkım, Y.T., \& Güllü, M. (2016). Investigation of the job satisfaction and burnout levels of the wrestling referees according to various factors in Turkey. Journal of Human Sciences, 13(2), 3469-3481. doi:10.14687/jhs.v13i2.4008

dimension points of the wrestling referees according to monthly average incomes $(p<0,05) .10$ different the two independent samples test have been conducted, and it has been observed as a results that this significant difference $(\mathrm{p}<0,005)$ occurs between the wrestling referees whose monthly average incomes are 1001-1500も (2) and the ones whose monthly average incomes are 2001-3000も (4).

Table 8. The Distribution of the Job Satisfaction and Professional Burnout Points of the Wrestling Referees according to Referee Categories

\begin{tabular}{|c|c|c|c|c|c|c|c|c|}
\hline $\begin{array}{l}\text { Scale / Sub- } \\
\text { dimensions }\end{array}$ & Referee Categories & $\mathrm{n}$ & $\begin{array}{l}\text { Mean } \\
\text { Rank }\end{array}$ & KW & sd & $\mathrm{p}$ & Groups & $\mathrm{p}$ \\
\hline \multirow{4}{*}{$\begin{array}{ll}\text { Job } & \text { Satisfaction } \\
\text { scale } & \end{array}$} & National & 92 & 58,33 & \multirow{4}{*}{7,167} & \multirow{4}{*}{3} & \multirow{4}{*}{0,06} & & \\
\hline & International III & 15 & 79,70 & & & & & \\
\hline & International II & 8 & 80,44 & & & & & \\
\hline & International I and Over & 11 & 72,32 & & & & & \\
\hline Emotional & National & 92 & 63,44 & \multirow{4}{*}{1,505} & \multirow{4}{*}{3} & \multirow{4}{*}{0,68} & & \\
\hline \multirow[t]{3}{*}{ Exhaustion } & International III & 15 & 58,53 & & & & & \\
\hline & International II & 8 & 77,38 & & & & & \\
\hline & International I and Over & 11 & 60,68 & & & & & \\
\hline \multirow[t]{4}{*}{ Depersonalization } & National & 92 & 61,05 & \multirow{4}{*}{12,317} & \multirow{4}{*}{3} & \multirow{4}{*}{$0,006^{*}$} & & \\
\hline & International III & 15 & 65,27 & & & & (1)-(3) & $0,001 * *$ \\
\hline & International II & 8 & 105,25 & & & & $(2)-(3)$ & $0,006^{* *}$ \\
\hline & International I and Over (4) & 11 & 51,23 & & & & (4)-(3) & $0,005^{* *}$ \\
\hline Personal & National & 92 & 60,76 & \multirow{4}{*}{6,947} & \multirow{4}{*}{3} & \multirow{4}{*}{0,07} & & \\
\hline \multirow[t]{3}{*}{ Accomplishment } & International III & 15 & 81,70 & & & & & \\
\hline & International II & 8 & 46,44 & & & & & \\
\hline & International I and Over & 11 & 74,05 & & & & & \\
\hline
\end{tabular}

In table 8 , it is observed that no significant difference $(\mathrm{p}>0,05)$ has been detected among the emotional exhaustion points, the personal accomplishment points, the job satisfaction according to the wrestling referees categories. However, a significant difference has been determined among the depersonalization points according to the wrestling referees categories $(p<0,05)$. It has been observed upon the 6 different two independent samples test that this significant difference $(p<0,008)$ occurs between the national referees (1) and international II referees (3) $(\mathrm{p}=0,001)$; between international III referees (2) and international II referees (3) $(p=0,006)$; and between international II (3) and international I referees $(4)(p=0,005)$.

Table 9. The Distribution of the Job Satisfaction and Professional Burnout Points according to Financial Income Levels of the Wrestling Referees

\begin{tabular}{lllllllll}
\hline Scale /Sub-dimension & Income & $\mathrm{n}$ & M.R. & $\mathrm{KW}$ & $\mathrm{sd}$ & $\mathrm{p}$ & Groups & $\mathrm{p}$ \\
\hline Job Satisfaction scale & Very little (1) & 34 & 47,79 & & & & & \\
& Little (2) & 63 & 66,57 & 9,746 & 2 & $\mathbf{0 , 0 0 8 *}$ & $(1)-(3)$ & $0,003^{* *}$ \\
& Adequate (3) & 29 & 75,24 & & & & & \\
\hline \multirow{3}{*}{ Emotional Exhaustion } & Very little & 34 & 61,56 & & & & & \\
& Little & 63 & 64,13 & 0,133 & 2 & 0,93 & & \\
& Adequate & 29 & 64,40 & & & & & \\
\hline \multirow{3}{*}{ Depersonalization } & Very Little & 34 & 60,43 & & & & & \\
& Little & 63 & 64,19 & 0,365 & 2 & 0,83 & & \\
& Adequate & 29 & 65,60 & & & & & \\
\hline Personal & Very Little & 34 & 63,13 & & & & & \\
Accomplishment & Little & 63 & 62,02 & 0,396 & 2 & 0,82 & & \\
& Adequate & 29 & 67,14 & & & & & \\
\hline & ${ }^{*} \mathrm{p}<0,05$ & & $7 * \mathrm{p}<0,016$ & after Bonferroni correction &
\end{tabular}


Ilkım, Y.T., \& Güllü, M. (2016). Investigation of the job satisfaction and burnout levels of the wrestling referees according to various factors in Turkey. Journal of Human Sciences, 13(2), 3469-3481. doi:10.14687/jhs.v13i2.4008

It is observed that there is a significant difference among the job satisfaction points of the wrestling referees according to their financial incomes $(\mathrm{p}<0,05)$ in table 9 . It has been observed upon the 3 different the two independent samples test that this significant difference occurs between the referees stating that their financial incomes are very little (1) and the ones stating that their financial incomes are adequate $(3)(p<0,016)$. No statistically significant difference was detected among the professional burnout sub-dimensions points (emotional exhaustion, depersonalization, personal accomplishment) according to the years ( $p>0,05)$.

Table 10. The Distribution of the Job Satisfaction and Professional Burnout Points of the Wrestling Referees according to Social Status viewpoints

\begin{tabular}{|c|c|c|c|c|c|c|c|c|}
\hline $\begin{array}{c}\text { Scale / } \\
\text { Sub-dimensions }\end{array}$ & $\begin{array}{l}\text { Referees Social } \\
\text { Status }\end{array}$ & $\mathrm{n}$ & $\begin{array}{l}\text { Mean } \\
\text { Rank }\end{array}$ & KW & df & $\mathrm{p}$ & Groups & $\mathrm{p}$ \\
\hline Job Satisfaction & Very low & 5 & 34,00 & \multirow{5}{*}{24,282} & \multirow{5}{*}{4} & \multirow{5}{*}{$0,00 *$} & \multirow{5}{*}{$\begin{array}{l}(2)-(5) \\
(2)-(6)\end{array}$} & \multirow{5}{*}{$\begin{array}{l}0,000^{* *} \\
0,002 * *\end{array}$} \\
\hline \multirow[t]{4}{*}{ scale } & Low & 32 & 45,09 & & & & & \\
\hline & Medium level (4) & 31 & 56,82 & & & & & \\
\hline & High & 44 & 78,26 & & & & & \\
\hline & Very high & 14 & 84,50 & & & & & \\
\hline Emotional & Very Low & 5 & 67,80 & \multirow{5}{*}{0,967} & \multirow{5}{*}{4} & \multirow{5}{*}{0,91} & & \\
\hline \multirow[t]{4}{*}{ Exhaustion } & Low & 32 & 68,30 & & & & & \\
\hline & Medium Level & 31 & 63,05 & & & & & \\
\hline & High & 44 & 60,61 & & & & & \\
\hline & Very High & 14 & 61,07 & & & & & \\
\hline \multirow[t]{5}{*}{ Depersonalization } & Very Low & 5 & 75,50 & \multirow{5}{*}{4,537} & \multirow{5}{*}{4} & \multirow{5}{*}{0,33} & & \\
\hline & Low & 32 & 71,42 & & & & & \\
\hline & Medium Level & 31 & 60,32 & & & & & \\
\hline & High & 44 & 56,38 & & & & & \\
\hline & Very High & 14 & 70,54 & & & & & \\
\hline Personal & Very Low & 5 & 65,80 & \multirow{5}{*}{0,236} & \multirow{5}{*}{4} & \multirow{5}{*}{0,99} & & \\
\hline \multirow[t]{4}{*}{ Accomplishment } & Low & 32 & 63,48 & & & & & \\
\hline & Medium Level & 31 & 60,94 & & & & & \\
\hline & High & 44 & 64,77 & & & & & \\
\hline & Very High & 14 & 64,39 & & & & & \\
\hline
\end{tabular}

In table 10, it is observed that there is a significant difference among the job satisfaction points of the wrestling referees according to their social status viewpoints $(p<0,05)$. It has been observed that this difference occurs between the groups who stated their social status as low (2) and the group who stated their social status as high (5) $(\mathrm{p}=0,000)$; and between the groups who stated their social status as low $(2)(\mathrm{p}=0,002)$ and those referees who stated their social status as very high $(6)(\mathrm{p}<0,005)$. No significant difference was detected among the professional burnout sub-dimensions points (emotional exhaustion, depersonalization, personal accomplishment) of the wrestling referees according to the social status viewpoints $(\mathrm{p}>0,05)$.

Table 11. The Relation between the Job Satisfaction and Professional Burnout Syndrome Levels of the Wrestling Referees

\begin{tabular}{lcccc}
\hline & Job Satisfaction & Emotional & Depersonalization & Personal \\
& Scale & Exhaustion & Dccomplishment \\
\hline Job Satisfaction Scale & 1,000 & $-0,255(\mathrm{p}<0,01)$ & $-0,097(\mathrm{p}>0,05)$ & $0,341(\mathrm{p}<0,01)$ \\
Emotional Exhaustion & $-0,255(\mathrm{p}<0,01)$ & 1,000 & $0,467(\mathrm{p}<0,01)$ & $-0,217(\mathrm{p}<0,05)$ \\
Depersonalization & $-0,097(\mathrm{p}>0,05)$ & $0,467(\mathrm{p}<0,01)$ & 1,000 & $-0,380(\mathrm{p}<0,01)$ \\
Personal Accomplishment & $0,341(\mathrm{p}<0,01)$ & $-0,217(\mathrm{p}<0,05)$ & $-0,380(\mathrm{p}<0,01)$ & 1,000 \\
\hline
\end{tabular}


Ilkım, Y.T., \& Güllü, M. (2016). Investigation of the job satisfaction and burnout levels of the wrestling referees according to various factors in Turkey. Journal of Human Sciences, 13(2), 3469-3481. doi:10.14687/ihs.v13i2.4008

As it is clear in table 11, there is a significant and weak negative relation between the job satisfaction and emotional exhaustion levels of the wrestling referees $(r=-0,255, p<0,01)$; a significant and very weak negative relation between the depersonalization $(r=-0,097, p<0,01)$; and a significant and weak positive relation between the personal accomplishment $(r=0,341, p<0,01)$. while it is clearly observed in table 10 that there is a significant and weak positive relation between the emotional exhaustion levels and depersonalization of the wrestling referees $(r=0,467, p<0,01)$, and there is a reverse weak relation between the personal accomplishment $(r=-0,217, p<0,01)$; there is a significant and weak negative relation between depersonalization and personal accomplishment $(r=-0,380, \mathrm{p}<0,01)$.

\section{Discussion and Conclusion}

As it is observed in table 4, it has been found that the job satisfaction levels of the wrestling referees are at the medium level; emotional exhaustion levels are at the high level, and depersonalization levels are at the medium level; and personal accomplishment perceptions are at the low level. These results show that the job satisfaction levels of the national and international wrestling referees are low, and their professional burnout levels are high. With a different expression within the literature findings, it is possible to claim that the wrestling referees do not feel adequate satisfaction for their jobs, become tired and worn in their jobs, lose their emotional and physical strengths, and behave as if there are objects instead of human beings in front of them to serve to when they work (Kurçer, 2005; Ertürk \& Keçecioğlu, 2012; Özipek, 2006).

It is clear in table 5 that there is no significant difference among the job satisfaction levels of the wrestling referees according to their ages. Can et al. (2010) conducted a study and reported that they did not find any significant differences between the Job Satisfaction levels of the handball referees according to the age variable. Akçamete et al. (2001) reported that age is not an influential variable on job satisfaction. Kargün (2011) conducted a study and did not find a statistically significant difference between the job satisfaction levels and the ages of the football referees. Similarly, Ulucan et al. (2011) and Vural (2001) conducted studies on football coaches and reported results that are similar to ours. The fact that there is no difference between the job satisfaction points of the referees and their ages shows that the wrestling referees are not influenced by age variable. The reason of this is considered to be the fact that the referees' are rewarded according to the games they manage not according to their ages, and they are integrated with their jobs at a high level.

According to table 5, no significant difference was detected among the burnout subdimensions (emotional exhaustion, depersonalization, personal accomplishment) points of the wrestling referees according to the age variable. Tekin et al. (2009), Baysal (1995) and Koustelios (2001) conducted studies and reported that age was not influential on emotional burnout. When the results of our study are examined it is observed that there is no significant difference between the Depersonalization levels of the referees according to age variable. The results of the study conducted by Çam (1989) and our results show parallelism. No significant difference was detected among the personal accomplishment levels of the referees according to age variable. This result shows parallelism with the results reported by Kitapçığlu (2000), Özbek and Girgin (1993), and Seğmenli (2001). It is observed according to the results of our study that the age parameter is not influenced by the burnout Sub-dimension (emotional exhaustion, depersonalization, personal accomplishment) variables.

When the job satisfaction levels of the wrestling referees are examined according to their marital status, it is clearly observed that the job satisfaction levels of the wrestling referees are higher than those of the single ones in table 6. However, upon the statistical comparisons among the groups, no significant difference has been detected between the group points. Karataş (2009) conducted a study and reported that the difference among the job satisfaction levels of the handball, basketball and volleyball classman referees were not statistically significant according to 
Ilkım, Y.T., \& Güllü, M. (2016). Investigation of the job satisfaction and burnout levels of the wrestling referees according to various factors in Turkey. Journal of Human Sciences, 13(2), 3469-3481. doi:10.14687/ihs.v13i2.4008

the marital status. Çetin (2001) conducted a study on sports specialists and reported that the marital status did not influence the job satisfaction levels, which is consistent with our results. However, Yildız et al. (2001) and Canbaz (2005) found opposite results in their studies, and reported that marriage ensured a regular life medium for the individuals and increased the job satisfaction levels.

According to Table 6, no significant difference has been detected among the burnout subdimension (emotional exhaustion, depersonalization, personal accomplishment) points of the wrestling referees according to their marital status. Our results and the results of the study conducted by Budak (2005), Özdemir (1999), Kurllmaz et al. (2013) show parallelism. In addition, Tatlıcı and Kırımoğlu (2008) conducted a study on athletics coaches and reported that there was no significant relation between marital status and burnout levels. Depending on this, it is possible to claim that the marital status variable is not influenced by burnout sub-dimensions (emotional exhaustion, depersonalization, personal accomplishment) of the wrestling referees.

In it observed in table 7 that there is no significant difference among the job satisfaction points of the wrestling referees according to their monthly average incomes. Sungur (2001) conducted a study and examined the socio-economic structure of the Turkish football referees, and determined that the socio-economic levels were at medium level. It was observed that the job satisfaction levels of the wrestling referees according to their monthly average incomes were at the medium level. it is considered that since working as a referee is made as a hobby rather than for financial income purposes, the financial issues do not influence this topic.

it is observed in table 7 that there is no significant difference among the personal accomplishment burnout points and depersonalization points of the wrestling referees according to the monthly average income levels. However, a significant difference has been detected among the emotionality burnout points of the referees. Bilici et al., (1998) Taycan et al., (2006) reported in their studies that as the income levels increased, the professional burnout levels decreased. These results support our findings.

It is observed in table 8 that there is no significant difference among the job satisfaction points according to referee categories. Karataş (2009) conducted a study and reported that there was no significant difference among the job satisfaction levels of the handball, basketball and volleyball classman referees according to the classman status. Çoknaz (1998) did not report a significant difference among the job satisfaction levels and the seniority of the team and individual sports coaches. The job satisfaction levels of the individuals are high just after they start job, and this level decreases in time. The possibility of the individuals coming to good centers also increases as their seniority and experiences increase in time. This situation makes referees receive much satisfaction from their jobs (Seçme, 2008). When our study is considered in general terms, it may be concluded that the referee categories are not influential on job satisfaction levels. It is also possible to conclude that the lack of significant difference among the points stems from the fact that there is no big difference among the categories in wrestling referees.

It is observed in table 8 that while no significant difference has been detected among the emotional exhaustions and personal accomplishment points according to the referee categories of the wrestling referees, there is a significant difference among the depersonalization points. It has been observed that this difference occurs between the national referees and international II referees; and between the international III referees and international II referees; and between the international II referees and international I. based on this result, it is possible to conclude that the category difference creates depersonalization on the wrestling referees. In addition, it is also possible to claim that there are negative influences of category differences on the burnout dimensions of the wrestling referees. It has been observed that the averages of the orders of the wrestling referees in international III group are high in personal accomplishment dimension; however, no significant difference has been detected in the statistical comparisons among the groups in terms of group points. In the personal accomplishment dimension, it is considered that there is no significant difference because of the fact that it is not influenced by this variable. 
Ilkım, Y.T., \& Güllü, M. (2016). Investigation of the job satisfaction and burnout levels of the wrestling referees according to various factors in Turkey. Journal of Human Sciences, 13(2), 3469-3481. doi:10.14687/ihs.v13i2.4008

it is observed in table 9 that there is a significant difference among the job satisfaction points of the wrestling referees according to the financial income levels. An adequate payment at a job ensures that the employee feels well at work. An inadequate payment gives rise to the negative attitudes of the employee at work (Günbay1, 2000). The difficulty level of a job influences the job satisfaction (Ünal, 2003). We have found a significant difference among the financial income levels of the referees and their job satisfaction levels; and when this is examined, it is observed that this difference occurs among the wrestling referees who find their financial income levels as adequate and those who find income levels as inadequate. The reason of this may be considered to be the fact that the wrestling federation of turkey determines the payments of the referees according to the expenses of a referee who is on active duty away. However, it is expected that a referee who goes away for a competition receives a financial income.

It is observed in table 9 that there is no significant difference between the burnout subdimension (emotional exhaustion, depersonalization, personal accomplishment) points of the wrestling referees according to their financial income levels. This result has revealed that the financial income does not influence the burnout levels.

It is observed in table 10 that there is a significant difference among the social status viewpoints of the wrestling referees and their job satisfaction points. It is observed that this difference occurs among the referees who stated their social status as low and those referees who stated their social status as high. when the job satisfaction levels of the wrestling referees are examined according to the social status viewpoints, it is observed that the job satisfaction levels of the referees who stated their social status as very high have been detected to be high when compared with the other groups; and in this context, it is possible to conclude that, for this reason, the wrestling referees are welcomed and hosted well in competitions that are away by the host referees and the close friends of the host referees. It is also possible to add the fact that the athletes, managers and coaches dealing with wrestling receive great respect as a reason for this.

In table 10, it shows that there is no significant difference among the burnout subdimensions (emotional exhaustion, depersonalization, personal accomplishment) points of the wrestling referees according to their social status. This situation shows that the social status perceptions of the wrestling referees do not influence professional burnout status.

As it is observed as the job satisfaction levels of the wrestling referees increase, the personal accomplishment levels increase, and their depersonalization levels and emotional exhaustion levels decrease in table 11. This result shows that if the job satisfactions or the personal accomplishment of the wrestling referees are increased, they will feel more respect for their profession, show emotional devotion and their job satisfaction levels will increase.

As a conclusion, it is possible to claim that the national and international wrestling referees in turkey do not have adequate satisfaction for their jobs; and they are experiencing professional burnout. As the job satisfaction levels of the wrestling referees increase; their depersonalization levels and emotional exhaustion levels decrease, and their personal accomplishment feelings increase. it has also been determined that the financial income and social status perceptions of the referees influence the job satisfaction levels of them, and their referee category levels and monthly average income levels influence their professional burnout levels.

\section{References}

Akçamete, G. Kaner, S. ve Sucuoğlu, B. (2001). Öğretmenlerde tükenmişlik, iş doyumu ve kişsilik. Ankara: Nobel Yayın Dağıtım.

Aslan, H. Aslan, R. O. ve Kesepara, C. (1997). Kocaeli’nde bir grup sağlık çalışanında işe bağlı gerginlik, tükenme ve iş doyumu. Toplum ve Hekim, 12, 24-9.

Bayraktar, G. ve Tozoğlu, E. (2015). Güreş sporuna küreselleşme sürecinin etkileri. Ă̆r İbrabim Çeçen Üniversitesi Sosyal Bilimler Enstitüsü Dergisi, 1 (2), 71-92. 
Ilkım, Y.T., \& Güllü, M. (2016). Investigation of the job satisfaction and burnout levels of the wrestling referees according to various factors in Turkey. Journal of Human Sciences, 13(2), 3469-3481. doi:10.14687/jhs.v13i2.4008

Baysal, A. (1995). Lise ve dengi okul ögretmenlerinde meslekte tükenmişliğe etki eden faktörler (Yayınlanmamış Doktora Tezi). Dokuz Eylül Üniversitesi Sosyal Bilimler Enstitüsü, İzmir.

Bilici, M. Mete, F. Soylu, C. Bekâroğlu, M. ve Kayakçı, Ö. (1998). Bir grup akademisyende depresyon ve tükenme düzeyleri. Türk Psikiyatri Dergisi, 9 (3), 181-190.

Budak, G. ve Sürgevil, O. (2005). Tükenmişlik ve tükenmişliği etkileyen örgütsel faktörlerin analizine ilişkin akademik personel üzerinde bir uygulama. D.E.Ü.İ.I.B.F. Dergisi, 20 (2), 95108.

Çam, O. (1989). Hemşsirelerde tükenmişslik sendromunun araştrmlması (Yüksek Lisans Tezi). Ege Üniversitesi Sağlık Bilimleri Enstitüsü, İzmir.

Can, Y. Soyer, F. ve Yllmaz, F. (2010). Hentbol hakemlerinin iş doyumu ve mesleki tükenmişlik düzeyleri arasındaki ilişkinin incelenmesi. Selçk Üniversitesi Beden Ë̆̈itimi ve Spor Bilim Dergisi, 12 (2), 113-119.

Canbaz, S. (2005). Manisa kent merkę̧inde çalsşan ebelerin iş doyumu ve biæmete yansimalar (Yayınlanmamış Yüksek Lisans Tezi). Celal Bayar Üniversitesi Sağlık Bilimleri Enstitüsü, Manisa.

Cei, A. (1994). Hakem psikolojisi. (A. Kin, Çev.) Futbol Bilim ve Teknoloji Dergisi, 6 (1), 21-24.

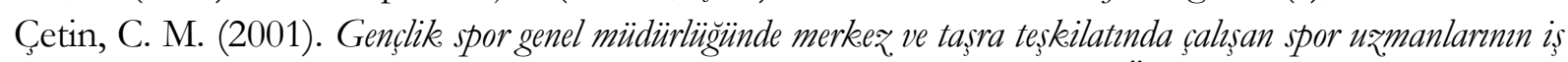
doyum düzeyleri (Yayınlanmamış Yüksek Lisans Tezi). Selçuk Üniversitesi Sağlık Bilimleri Enstitüsü, Konya.

Çoknaz, H. (1998). Takım ve bireysel spor antrenörlerinin is doyumu düzeylerinin karşılaştırlması. (Yayımlanmamış Yüksek Lisans Tezi). Abant İzzet Baysal Üniversitesi Sosyal Bilimler Enstitüsü, Bolu.

Ergin, C. (1999). Doktor ve hemşirelerde tükenmişlik ve Maslach tükenmişlik ölçeğinin uyarlanması. VII. Ulusal Psikoloji Kongresi Bilimsel Çalışmaları, Türk Psikologlar Derneği Yayını, 143-154.

Ertütk, E. ve Keçecioğlu, T. (2012). Çalışanların iş doyumları ile mesleki tükenmişlik düzeyleri arasındaki ilişkiler: öğretmenler üzerine örnek bir uygulama. Ege Akademik Bakış Dergisi, 12 (1), 39-52.

Gökdemir, K. (1991). Karakucak güreş projesi doğrultusunda müsabaka yöntemi (Yayımlanmış Doktora Tezi). Marmara Üniversitesi Sağlık Bilimleri Enstitüsü, İstanbul.

Güler, M. (1990). Endüstri işletmelerinin iș doyumu ve depresyon, kaygu ve diğer baž değişkenlerin etkisi (Yayınlanmamış Doktora Tezi). Hacettepe Üniversitesi Sosyal Bilimler Enstitüsü, Ankara.

Günbayı, İ. (2000). Örgütlerde is doyumu ve güdülenme, Ankara: Özen Yayımcllı.

Karataş, Ö. (2009). Hentbol, basketbol, voleybol klasman bakemlerinin iş doyumu düzeylerin incelenmesi (Yayınlanmamış Yüksek Lisans Tezi). Fırat Üniversitesi Sağlık Bilimleri Enstitüsü, Elazığ.

Kargün, M. (2011). Türk futbol bakemlerinin is doyumu ve mesleki tükenmişlik düzeylerinin incelenmesi (Yayınlanmamış Yükseklisans Tezi). İnönü Üniversitesi Sağlık Bilimleri Enstitüsü, Malatya.

Kırlmaz, A. Y. Çelen, Ü. ve Sarp, N. (2013). İlköğretim'de çalışan bir öğretmen grubunda tükenmişlik durumu araştırması. Ankara Üniversitesi Sağhlk Ĕgitim Fakültesi İlkögretim-Online, 2 (1), 2-9.

Kitapçıŏlu, G. (2000). Bornova sağhle grup başkanlĭg bölgesinde görev yapan ebelerin iş güclï̈̆̈̈ faktörlerinin belirlenmesi ve iş doyumu, tükenmişlik, örgütsel bağglık üzerine etkisi (Yayınlanmamış Uzmanlık Tezi). Ege Üniversitesi Tip Fakültesi, İzmir.

Koustelios, A. (2001). Burnout among Greek sport centre employees. Sport Management Review, 4 (2), 151-163.

Kurçer, M. A. (2005). Harran Üniversitesi tup fakültesi hekimlerinin iş doyumu ve tükenmişlik düzeyleri. Harran Üniversitesi Thp Fakültesi Dergisi, 3, 10-15.

Maslach, C. and Jackson, S. E. (1981). The measurement of experienced burnout. Journal of Occupational Behaviour, 2, 99-113. 
Ilkım, Y.T., \& Güllü, M. (2016). Investigation of the job satisfaction and burnout levels of the wrestling referees according to various factors in Turkey. Journal of Human Sciences, 13(2), 3469-3481. doi:10.14687/jhs.v13i2.4008

Özbek, K ve Girgin, G. (1993). Să̆hlk bakanhğ il teșkilatında çalısan pratisyen bekimlerde tükenmişlik sendromunun araştırlması, Ankara: Sağlık Bakanlığ1 Ruh Sağlığı Bülteni.

Özdemir, A. K. Özdemir, H. D. Coşkun, A. ve Çınar, Z. (1999). Diş hekimliği fakültesi öğretim elemanlarında mesleki tükenmişlik ölçeğinin değerlendirilmesi. Cumburiyet Üniversitesi Diş bekimliği Fakültesi Dergisi, 2 (2), 98-104.

Özipek, A. (2006). Orta ögretim okullarnda görev yapan ögretmenlerde mesleki tükenmislilk düreyi ve nedenleri (Yüksek Lisans Tezi). Trakya Üniversitesi Sosyal Bilimler Enstitüsü, Edirne.

Seçme, T. (2008). Beden eğitimi ve spor ögretmenlerinin is doyum düreylerinin belirlenmesi: Afyonkarabisar örneği. (Yayınlanmamış Yüksek Lisans Tezi). Afyon Kocatepe Üniversitesi Sağlık Bilimleri Enstitüsü, Afyon.

Seğmenli, S. (2001). Rehber öğretmenlerinin tükenmislike düzeylerinin incelenmesi (Yayınlanmamış Yüksek Lisans Tezi). Hacettepe Üniversitesi Sosyal Bilimler Enstitüsü, Ankara.

Sucuoğlu, B. ve Kuloğlu, N. (1996). Özürlü çocuklarla çalışan öğretmenlerde tükenmişliğin değerlendirilmesi. Türk Psikoloji Dergisi, 10, 44-60.

Sülün, Ö. (2013). Futbol hakemlerinin öfke ve kerggmhle düreyleri ile empatike eğilim dürgeylerinin karşılaștırılması (YayımlanmamışYükseklisans Tezi). Karamanoğlu Mehmetbey Üniversitesi Sosyal Bilimler Enstitüsü, Karaman.

Sungur, E. (2001). Türk futbol hakemlerinin sosyo-ekonomik yapılarmın incelenmesi (Yayınlanmamış Yüksek Lisans Tezi). Sakarya Üniversitesi Sosyal Bilimler Enstitüsü, Sakarya.

Sünter, A. T. Canbaz, S. Dabak, Ş. Öz, H. ve Pekşan, Y. (2006). Pratisyen hekimlerde tükenmişlik, işe bağlı gerginlik ve iş doyumu düzeyleri. Genel Tap Dergisi, 16 (1), 9-14.

Tatlıc1, M. ve Kırımoğlu, H. (2008). Atletizm antrenörlerinin mesleki tükenmişlik düzeylerinin incelenmesi. Niğde Üniversitesi Beden Eğitimi ve Spor Bilimleri Dergisi, 2 (1), 34-47.

Taycan, O. Kutlu, L. Çimen. S. ve Aydın, N. (2006). Bir üniversite hastanesinde çalışan hemşirelerde depresyon ve tükenmişlik düzeyinin sosyodemografik özelliklerle ilişkisi. Anadolu Psikiyatri Dergisi, 7, 100-108.

Tekin, M. Taşğın, Ö. ve Baydil, B. (2009). Çeşitli değişkenlere göre taekwondo hakemlerinin tükenmişlik düzeylerinin belirlenmesi. Kastamonu Eğitim Dergisi, 17 (3), 1001-1012.

TLA (2016). Turkish Language Association, Turkish Dictionary. The access date: 20.05.2016 http://www.tdk.gov.tr/index.php?option=com gts

Tekgöz, Ü. (2013). Futbol hakemlerinin is stresi, is tatmini ve yaşam tatmin düzeyleri arasindaki iliskilerin incelenmesi: 3. bölge bakemleri üzerinde bir araștırma (YayımlanmamışYükseklisans Tezi). Erciyes Üniversitesi Sağlık Bilimleri Enstitüsü, Kayseri.

Ulucan, H. Erol, A. E. Bektaş, F. ve Yılmaz, İ. (2011). Türkiye'deki profesyonel futbol kulüplerinin alt yapılarındaki antrenörlerin iş doyum düzeylerinin incelenmesi. Selçu Üniversitesi Beden Eğitimi ve Spor Bilimleri Dergisi, 13 (2), 226-232.

Ünal, Z. (2003). Ögrretmenlerde is doyumu ve örgütsel vatandaşllk (Yüksek Lisans Tezi). Afyon Kocatepe Üniversitesi Sosyal Bilimler Enstitüsü, Afyon.

Vural, H. (2001). Ankara ilinde bulunan amatör futbol antrenörlerinin iş doyum düzeylerin saptanmast (Yayınlanmamış Bitirme Tezi). Hacettepe Üniversitesi Spor Bilimleri ve Teknolojisi Yüksekokulu, Ankara.

Yıldız, N. Yolsal, N. Ay, P. ve Kıyan, A. (2003). İstanbul Tıp Fakültesi'nde çalışan hekimlerde iş doyumu. İstanbul Tap Fakültesi Mecmuası, 66 (1), 34-41. 